\title{
The Impact of Economic Factors on the 2011 Turkish General Election*
}

\author{
Harun Yüksel ${ }^{* *}$ \\ Fatih University
}

\author{
Abdülkadir Civan*** \\ Gediz University
}

\begin{abstract}
This study examines the outcomes of the general election which took place on 12 June 2011. We analyze the effects of economic indicators on the results of June general election by using the provincial data. The Seemingly Unrelated Regression (SUR) technique is used in the estimations. We find that the political parties preserved their core voters or sympathizers. Provincial economic growth positively affects the AKP (Justice and Development Party) but the MHP (Nationalist Movement Party) negatively as expected. However, it does not have any influence on the CHP (Republican People's Party). Provinces suffering from higher unemployment rates do not vote for the AKP while opposition parties are not affected by unemployment rates. It is also found that vote share of the incumbent party does not increase in the provinces in which higher public spending has been made by the AKP. In terms of regions, our results indicate that the ruling party increased its vote share more in the provinces where the voters are of average or higher level of income and education.
\end{abstract}

Keywords: 2011 Turkish General Elections; Voter Behavior; Turkey; Economic Voting.

JEL Classification: D72.

\section{Ekonomik Faktörlerin 2011 Türkiye Genel Seçimlerine Etkisi}

\section{Özet}

Bu çalışma 12 Haziran 2011 genel seçim sonuçlarını değerlendirmektedir. Ekonomik eğilimlerin Haziran genel seçim sonuçları üzerine etkisini il düzeyinde veri kullanarak analiz edilmektedir. Ekonometrik model tahmininde Görünürde Bağlantısız Regresyonlar kullanılmıştır. Sonuçlara göre siyasi partiler kendi tabanlarını korumuşlardır. İl düzeyinde ekonomik büyüme beklendiği gibi AKP'ni (Adalet ve Kalkınma Partisi) pozitif yönde etkilerken MHP'ni (Milliyetçi Hareket Partisi) olumsuz yönde etkilemiştir. Fakat CHP (Cumhuriyet Halk Partisi) üzerinde herhangi bir etkisi bulunmamıştır. Muhalefet partileri işsizlik oranından etkilenmezken, işsizlik oranının yüksek olduğu illerde AKP oy alamamıştır. Çalışmada ayrıca AKP'nin daha yüksek kamu harcamaları yaptığı

\footnotetext{
* We would like to thank anonymous referees for very helpful comments on this paper. All remaining errors are our own.

** Harun Yüksel is an Assistant Professor in the Department of Economics at Fatih University, 34500, Büyükçekmece, Istanbul, Turkey.E-mail: hyuksel@fatih.edu.tr

*** Abdülkadir Civan is an Associate Professor in the Department of Economics at Gediz University, Hürriyet Bulvarı, No: 10/1, 35130, Çankaya, Izmir, Turkey. E-mail: abdulkadir.civan@gediz.edu.tr
} 
illerde iktidar partisinin oy oranının artmadığı bulunmuştur. Bölgelere baktığımızda, çalışmamızın sonuçları iktidar partisinin ortalama veya daha da üzeri gelir ve eğitime sahip illerde oy oranını daha da arttırdı ğını göstermektedir.

Anahtar kelimeler: 2011 Türkiye Genel Seçimleri; Seçmen Davranışı; Türkiye; Ekonomik Oylama. JEL Sinıflandirmasi: D72.

$\mathrm{T}$ This paper provides an empirical analysis on the outcomes of the June 2011 general election by emphasizing the responses of voters to the macroeconomic performances of the incumbent government. Classical economic voting theory will be considered as a basis in analyzing the effects of economic conditions on the election results. This theory argues that voters aim to reward incumbents at the polls when they are satisfied with their past performances while they tend to punish incumbent parties displaying a poor economic performance. A widely accepted conviction is that economic voting exists but comes along with a wide range of democratic settings. Income growth, unemployment rate and inflation are the most used macroeconomic variables in the empirical analyses when examining a government's economic performance.

As the voters do not only consider the economic performance of the incumbent party while they decide on whom to vote for, the vote shares of parties in the previous elections are included in the analysis in order to control for political inertia. In the estimations, the Seemingly Unrelated Regression technique (SUR) is used in order to account for the political inertia. This model allows for the estimation of the system of equations while simultaneously accounting for the correlated errors. In addition, we use dummy variables for several Turkish provinces that show similar voting patterns in previous elections in order to control for other dimensions of decision making processes of voters.

The results show that a higher economic growth rate at the provincial level improves the AKP's vote share, but decreases the MHP's votes. However, it does not have any influence on the CHP's votes. Unemployment rates are positively associated with the votes of the AKP while opposition parties are not affected by unemployment rates. The study also found that relatively higher public spending made in some provinces by the incumbent party does not increase its share of the vote. This paper is organized in the following manner: Section 2 gives a brief review of economic voting theory and some studies that empirically analyze the election outcomes in Turkey. In Section 3, the 2011 general election results are evaluated in terms of party performances. Data and methodology are presented in Section 4 while results of this empirical analysis are reported in Section 5. Finally, Section 6 concludes the paper.

\section{Economic Voting}

The most widely used formulation of economic voting theory is that electoral chances of incumbent politicians are greatly influenced by the macroeconomic situation prior to the election (Whitten, 2004). As voters are short-term rational actors, their perceptions regarding the incumbent's role in the economic development and change constitute the 
main deterministic factor of economic voting (Ercins, 2007). Economic voting tends to evaluate the influence of overall economic performance mainly in terms of income, unemployment, burden of taxation, inflation and income transfers and public investments. Thus, when voters are satisfied with the economic performance of the incumbent party for the past period, they support it at the poll; otherwise, they withdraw their support (Lewis-Beck and Stegmaier, 2004; Akarca and Tansel, 2007). ${ }^{[1]}$ Naturally, other than these general macroeconomic indicators; ideologies and specific economic interests also shape their voting behavior.

There is a comprehensive literature that examines the voter response to the economic performance. In the broadest sense, it is argued that economic evaluations of voters have a statistically significant impact on the support given to the incumbent party. ${ }^{[2]}$ Despite this common perception, it has been indicated in many studies that the vote of an individual during an elections is shaped regardless of the economic performance of the ruling party. These studies have also revealed that perceptions by voters regarding the economic situation are influenced by partisanship. By this way, people who are strictly devoted to the incumbent party would perceive economic activities of the government positively (Evans and Anderson, 2006; Gerber and Huber, 2009; Fraile and Lewis-Beck, 2010).

The voting behavior generally depends on the voters' retrospective evaluations or prospective assumptions concerning economic policies. Due to the uncertainty about the future and the sincerity of the parties or candidates, voters take the past actions of the parties into consideration in deciding whom to vote for at elections (Başlevent et al., 2005). Akarca (2011) stated that voters also tend to be myopic in evaluating the economy, in general by considering only the recent years. ${ }^{[3]}$ Moreover, they not only consider their own economic situation but also that of other people around them.

In the literature, numerous empirical analyses have been conducted to examine the voter response to economic conditions. ${ }^{[4]}$ However, there are limited numbers of empirical studies on economic voting in Turkey. For instance, Çarkoğlu (1997) analyzed 21 elections from 1950 to 1995 in order to examine the macroeconomic influences on electoral support. In his study, he found that while increases in unemployment and inflation rates decrease the support of voters for the incumbents, higher growth rates increase the support. Akarca and Tansel (2002) examined the relation between vote shares of parties and economic growth for the 1991 and 1995 general elections. They concluded that the incumbent parties of those years had benefited from a good macroeconomic performance. Başlevent et al. (2005) examined both economic and non-economic factors

\footnotetext{
[1] The rationale behind this concept is that the voters know how to interpret aggregate economic data and judge the economic performance of the government.

${ }^{[2]}$ For more details, see Nannstad and Paldam (1994).

[3] Short lags (the evaluation period of economic activities for voters), of one or two years are also used In the literature. For further details see Paldam (1991:14).

[4] See the Special Issue of Electoral Studies (Volume 19, Issue 2-3) on economic voting, Paldam (1991) and Lewis-Beck and Stegmaier (2000) for a review.
} 
that shape the party preferences of citizens in Turkey. Their empirical results provide evidence in support of the economic voting theory. In another analysis of Akarca and Tansel (2006), in which they examined 25 general and local elections, they found that growth and inflation are two important parameters affecting the party preferences of voters. They emphasized their findings by stating that Turkish voters take the government's economic performance into account in the elections (Akarca and Tansel, 2007). Köksal et al. (2010) studied the 2009 local elections to determine whether the economic conditions affected the results, finding that the economic crisis adversely affected the incumbent party especially in some provinces. Yüksel et al. (2011) conducted a study on the impacts of economic and political factors on the preferences of voters in the 2010 Turkish referendum. Results of this research indicated that referendum votes were higher in the provinces where economic conditions were getting relatively better. Finally, prior to the June 2011 general elections in Turkey, Akarca (2011) predicted the vote share that the incumbent party would take would be about 44 percent of the votes based on its economic performance in recent years and general economical situation throughout the country.

\section{Results of the June 2011 General Election}

Turkey's general election which took place on 12 June 2011 resulted in an expected but still impressive victory for the ruling party, the AKP. After two consecutive terms, the ruling AKP won the elections once more by receiving almost one-half of the votes and became the first political party to win three consecutive elections with an increase in its votes. The AKP broke its own record of the 2007 general election by receiving $49.8 \%$ of the nationwide votes in this election, which almost doubled the vote rate of the main opposition party, the Republican People's Party. Despite this overwhelming victory, the AKP's deputy numbers in the parliament decreased from 341 to 327 compared to previous elections. Afyon, Ağrı, Hakkari, Konya, Tokat, Trabzon and Yozgat are the provinces that the AKP saw a decrease in the number of deputies by two and Balıkesir, Bingöl, Bitlis, Bolu, Çorum, Elazı ̆̆, Erzincan, Erzurum, Isparta, Iğdır, Kastamonu, Kütahya, Malatya, Mardin, Sinop, Van, Bayburt and Karabük by one. On the other hand, the AKP increased its deputy number by seven in Istanbul, by two in Gaziantep and Izmir, by one in Ankara, Antalya, Bursa, Kayseri, Kocaeli, Rize and Şanlıurfa. ${ }^{[5]}$ Consequently, there is a net loss of 14 seats in the parliament according to the previous general election results for the AKP. For example, despite the increase in vote the share of the AKP from 64\% to $69 \%$ in Konya and from $56 \%$ to $59 \%$ in Trabzon, it decreased its related seats by two. This meant that the AKP would need about 40 deputies more to obtain the two-thirds majority needed for any possible constitutional amendment alone even without a referendum plebiscite. The AKP could not even secure 330 deputies, the number legally required to hold a referendum for a new constitution. One of the reasons of the decrease in the number of the AKP deputies in the parliament, though

[5] TUIK, http://tuikapp.tuik.gov.tr/secimdagitimapp/secim.zul, 1.04.2013. 
their votes increased, was the decision of the Supreme Committee of Elections (YSK) which changed the number of seats allocated to the electoral districts. While the number of seats was reduced in 28 districts, it increased in 14 districts. Göksel and Çınar (2011) exactly calculated the impact of the YSK rearrangement on the number of seats by the d'Hondt method. According to their results the AKP would have won almost 5 more seats in the parliament if the number of seats allocated to the districts remained unchanged.

The AKP won 66 of the 81 provinces. In general, it raised its vote share in the western part of the country while that decreased in the eastern part. It surpassed the CHP in Çanakkale, Eskişehir and Antalya and the Nationalist Movement Party (MHP) in Manisa, Balıkesir and Uşak. Tunceli, Hakkari and Iğdır are the only provinces from which the AKP does not have any deputy in the parliament.

Table 1

Vote Shares of Parties

\begin{tabular}{l|c|c|c|c|c}
\hline $\begin{array}{l}\text { Political } \\
\text { Parties }\end{array}$ & $\begin{array}{c}\text { November 2002 } \\
\text { General } \\
\text { Election }\end{array}$ & $\begin{array}{c}\text { March 2004 } \\
\text { Local } \\
\text { Election }\end{array}$ & $\begin{array}{c}\text { July 2007 } \\
\text { General } \\
\text { Election }\end{array}$ & $\begin{array}{c}\text { March 2009 } \\
\text { Local } \\
\text { Election }\end{array}$ & $\begin{array}{c}\text { June 2011 } \\
\text { General } \\
\text { Election }\end{array}$ \\
\hline AKP & 34.3 & 41.7 & 46.6 & 38.4 & 49.8 \\
\hline CHP & 19.4 & 18.2 & 20.9 & 23.1 & 26 \\
\hline MHP & 8.4 & 10.5 & 14.3 & 16 & 13 \\
\hline BDP & 6.2 & 5.2 & - & 5.6 & 6.5 \\
\hline
\end{tabular}

The CHP increased its voting share from 20.9 to 26 percent and its number of seats from 112 to 135 in this election. However, the number of provinces that the CHP could not send any deputy to the parliament rose from 33 to 36. Ardahan, Erzincan, Tunceli, Malatya, Adiyaman and Gaziantep are the only provinces from eastern and southeastern Anatolia for which the CHP will be represented in the Grand National Assembly of Turkey (TBMM). The main opposition party maintained its superiority only in the three coastal provinces of İzmir, Aydın and Muğla whereas it was the winning party in the south-western and western part of the country as it had been in the previous local election.

While some analysts had predicted that the MHP would not be able to surpass the $10 \%$ election threshold, it managed to receive $13 \%$ of all votes in the 2011 general elections. According to this vote distribution, the AKP won 327 seats, the CHP won 135 seats and the MHP had 53 seats. The only province where the MHP became the first party was Iğdır. The Peace and Democracy Party (BDP), which entered the general election with independent candidates in order to overcome the barrier of the $10 \%$ election threshold, won 35 seats in total. The BDP and the CHP were the political parties that increased their deputy numbers in the parliament when compared to the previous election. The independent candidates won about $6.5 \%$ of votes in all. 


\section{Data and Methodology}

The objective of our study is to explain the 2011 election results. Therefore, we proposed several economic, political and social hypotheses and tested them statistically. Our general approach to the issue is that the incumbent party (AKP) would benefit from the economic development of the country while the opposition parties would benefit from the failure of the incumbent party. We utilize provincial data so as to test our hypothesis. There are actually 85 election regions. However, since this study uses provincial data, the observation number is 81 for each party. Income growth, unemployment rate and inflation rate are the macroeconomic variables frequently used in order to assess the success of a government. Thus, we want to test the effects of these macroeconomic variables on the votes received by the AKP at the provincial level. But, unfortunately, some recent data are not available on the provincial level. In previous papers, we had used tax revenue as the indicator of the income level of provinces. Under normal conditions, tax revenue might not be a good indicator of the income level of individuals or provinces especially in the countries like Turkey where the size of the underground economy is substantial. However, what we were interested in was the changes in the income of a province rather than its absolute income level. Hence, we believed that changes in tax revenues could represent the changes in the income levels of provinces. An examination of the data of the period between 1990 and 2001 including both income levels and tax revenues supported our thought. The correlation coefficient between income growth rates and tax revenue growth rates is greater than 0.95 on the provincial level. ${ }^{[6]}$ Therefore, we use the tax revenue growth rate following the last election (2007) as one of the explanatory variables in the analysis. The data were obtained from the website of the General Directorate of Public Accounts.

Likewise, inflation rates are not available on the provincial level. The Turkish Statistics Institute divides Turkey into 26 statistical regions mostly due to administrative purposes and provides inflation data according to this regional division. So, we address inflation rate with this regional level. This division slightly reduced the accuracy of inflation data on the provincial level but we believe that this slight inaccuracy would be better than if we had excluded it completely.

Provincial unemployment rates are being calculated and announced annually by the Turkish Statistics Institute at the Statistical Region Units (SRE) level 3 from the year 2008. As the Statistics Institute announces in its Press Releases, producing statistics for sub geographical areas requires quite high sampling sizes and this is not preferred in consideration of both the infrastructure facilities and cost limits. Producing estimates for sub regions especially requires a very high sample size for the countries having an excessive population, a large area and too many and widely scattered settlements as Turkey does. It should be considered that these basic labor force indicators produced

${ }^{[6]}$ Correlation for recent years cannot be made because the Turkish Statistics Institute stopped publishing incomes at the provincial level at 2001. For a more discussion about that see Köksal, Civan and Genç (2010) and Yüksel, Civan and Erdoğan (2011). 
on the province level are obtained indirectly. ${ }^{[7]}$ Thus, we use unemployment rates at the regional level as in inflation data because of relative confidence. ${ }^{[8]}$

Unlike income growth, the effects of inflation and unemployment are generally felt in the short run. Thus, we use only the last year's inflation and unemployment rates as explanatory variables. As a matter of fact, Akarca and Tansel (2006) determined in their study that Turkish voters forget about the government's performance after one year.

Obviously, voters do not only consider the economic performance of the incumbent party while they decide on whom to vote for. We include the vote shares of parties in the previous elections in the analysis in order to control for political inertia. Moreover, we use dummy variables for several Turkish provinces that show similar voting patterns in previous elections in order to control for the other dimensions of decision making processes of voters. West (2005) and Akarca and Başlevent (2009) showed that Turkey can be divided into three regions which have similar voting patterns. Based on the study of Akarca and Başlevent (2009) ${ }^{[9]}$, we use the following regions to represent voting patterns in Turkey:

Figure 1

\section{Regions in Turkey Based on Voting Patterns}

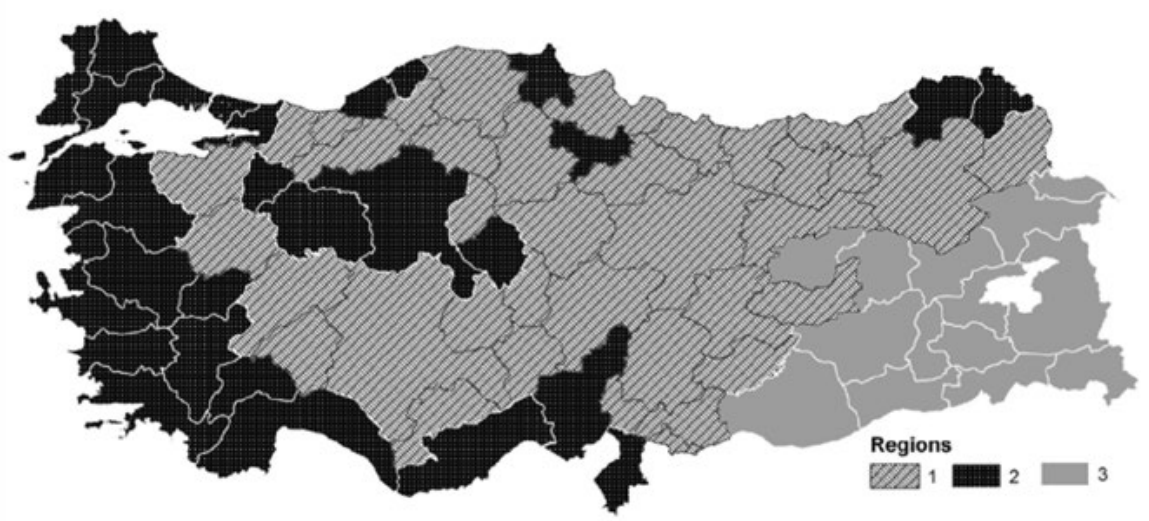

Region 1: Adlyaman, Afyon, Aksaray, Bayburt, Bolu, Bursa, Çankırı, Çorum, Düzce, Elazı̆̆, Erzincan, Erzurum, Gaziantep, Giresun, Gümüşane, Isparta, Kahramanmaras,, Karabïk, Karaman, Kars, Kastamonu, Kayseri, Kilis, Kırıkkale, Konya, Kütahya, Malatya, Nevşehir, Niğde, Ordu, Osmaniye, Rize, Sakarya, Samsun, Sivas, Tokat, Trabzon, Yozgat;

\footnotetext{
[7] For further details, http://www.tuik.gov.tr/PreHaberBultenleri.do?id=8536.

${ }^{[8]}$ In addition, we have repeated our analysis; according to the provincial unemployment data, there isn't any noteworthy change in coefficients. Only the marginally significance of the unemployment effect on the AKP vote share becomes insignificant. The $t$-statistic value of the correlation decreases from -1.76 to -1.11 by using provincial unemployment rates.

${ }^{[9]}$ For a more discussion about the cluster analysis see Akarca and Başlevent (2009) and Akarca (2009b).
} 
Region 2: Adana, Amasya, Ankara, Antalya, Ardahan, Artvin, Aydın, Balıkesir, Bartın, Bilecik, Burdur, Çanakkale, Denizli, Edirne, Eskişehir, Hatay, İstanbul, İzmir, Kırklareli, Kırşehir, Kocaeli, Manisa, Mersin, Muğla, Sinop, Tekirdağ, Uşak, Yalova, Zonguldak;

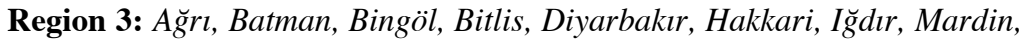
Muş, Siirt, Şırnak, Tunceli, Urfa, Van.

Akarca (2009b) describes Region 2 as a region which generally represents the voters who have income and education levels above the average while Region 3 consists of provinces which are less-developed and less-populated, mostly by ethnic Kurds. Lastly, Region 1 remains between Region 2 and Region 3 in many respects.

Social transfer programs and other public expenditures can also sway the satisfaction level of voters with the incumbent party. During the election campaign, there were controversies about the misuse of social transfer programs in order to influence the choices of voters. ${ }^{[10]}$ Thus, in order to test that alleged influence, we collected the data of per capita government expenditure from the website of the General Directorate of Public Accounts.

We also examine the effects of these variables on the vote shares of the opposition parties (CHP and MHP) in the elections.

Based on above-mentioned hypotheses, we estimate the following system of equations.

$$
\begin{aligned}
& A K P_{i}=\beta_{10}+\beta_{11} \text { AKP2007 }_{i}+\beta_{12} \text { Inflation }_{i}+\beta_{13} \text { Unemployment }_{i}+\beta_{14} \text { Growth }_{i} \\
& +\beta_{15} \text { PubExpenditure }{ }_{i}+\beta_{16} \text { Region } 1 \text { Grwth }_{i}+\beta_{17} \text { Region } 2 \text { Grwth }_{i} \\
& +\beta_{18} \text { Region } 1 \text { PbSpnd }_{i}+\beta_{19} \text { Region } 2 \text { PbSpnd }_{i} \\
& +\beta_{110} \text { Region } 1+\beta_{111} \text { Region } 2+\varepsilon_{i} \\
& \text { CHP }_{i}=\beta_{20}+\beta_{21} \text { CHP2007 }_{i}+\beta_{22} \text { Inflation }_{i}+\beta_{23} \text { Unemployment }_{i}+\beta_{24} \text { Growth }_{i}
\end{aligned}
$$

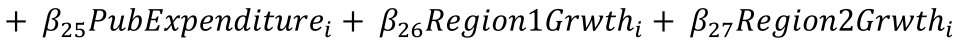

$$
\begin{aligned}
& +\beta_{28} \text { Region } 1 \text { PbSpnd }_{i}+\beta_{29} \text { Region } 2 \text { PbSpnd }_{i} \\
& +\beta_{210} \text { Region } 1+\beta_{211} \text { Region } 2+\varepsilon_{i} \\
& \text { MHP }_{i}=\beta_{30}+\beta_{31} \text { MHP2007 }_{i}+\beta_{32} \text { Inflation }_{i}+\beta_{33} \text { Unemployment }_{i}+\beta_{34} \text { Growth }_{i}
\end{aligned}
$$

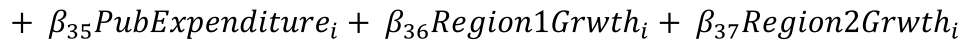

$$
\begin{aligned}
& +\beta_{38} \text { Region } 1 \text { PbSpnd }_{i}+\beta_{39} \text { Region } 2 \text { PbSpnd }_{i} \\
& +\beta_{310} \text { Region } 1+\beta_{311} \text { Region } 2+\varepsilon_{i}
\end{aligned}
$$

Region 3 is excluded from all dummy variables. We do not use interaction dummies for inflation and unemployment variables since they are not accurately measured on the provincial level but are determined on the statistical regional level the by Turkish Statistical Institute. Including those artificial regions with voting regions would increase the

${ }^{[10]}$ See Evans (2006) for a discussion about the issue. 
inaccuracy of results, so we refrain from such an interaction. In the estimations, the SUR technique is used, allowing the estimation of the system of equations while simultaneously accounting for the correlated errors. In the case of correlated errors in the models, Ordinary Least Squares (OLS) leads to inefficient estimates of the coefficients and standard errors. The Breusch-Pagan test of independence rejects independence of the error terms at a 5\% level of significance. If the error terms are uncorrelated, there will be no payoff to estimate the equations as a system (with SUR).

\section{Results and Discussion}

Table 4 presents the results of estimation of the system in equations 1 to 3 by the SUR model. First, we analyzed whether the political parties preserved their core votes. To this end, we included the vote share obtained by the party in the previous general election (2007) in each estimation as an independent variable. For all of the three parties, the vote share obtained in the previous election in the respective province had a significant and positive effect on the vote share gained in the 2011 elections. Although they are all statistically significant at a $0.01 \%$ level, the magnitude of coefficients on the previous election vote shares are different. The biggest coefficient belongs to the AKP while the smallest one belongs to the CHP. This difference can be loosely interpreted as those AKP voters, in the absence of any other changes in the economic environment, were the most loyal to their party whereas the CHP voters were the least loyal. Moreover, it is possible that there may be some other underlying factors influencing these coefficients which were not controlled in our estimations. In any case, the coefficient of 0.92 of the AKP for the previous election vote share variable is quite high and suggests that, ceteris paribus, the AKP preserved $92 \%$ of its voters. This is especially remarkable since the incumbent party usually loses its vote share more than the opposition parties in multi-party democracies. ${ }^{[11]}$ Akarca (2011) stated in his study where he analyzed all elections held in Turkey between 1950 and 2009 that incumbent parties generally lose $12.1 \%$ of their votes when compared to the previous election. Thus, we can conclude that cost of ruling for the AKP became lower than expected in the light of Turkish political history.

Secondly, we studied the effects of economic conditions on the votes of the incumbent and the opposition parties. Income growth rates affected the voting behaviors as expected. The incumbent party gained more votes in the provinces where economic growth was high. For example, suppose that province A grew by 10\% between 2007 and 2011 and province B did not grow at all. According to our estimations, the incumbent party the AKP receives $3.6 \%$ more votes in province A. The opposition party, the MHP, lost more votes in the provinces where economic growth was high as was expected. However, unlike the MHP, another opposition party, the CHP, was not adversely influenced by the economic growth. This can be attributed to the fact that the AKP and MHP party bases are socially and ideologically closer to each other than the AKP and CHP party bases. Therefore, economic factors might have been the distinctive issue for voters in choosing between the AKP and MHP rather than between the AKP and CHP.

${ }^{[11]}$ See Akarca (2011) for a discussion on that issue. 
Table 2

Summary of the List of Variables and Their Expected Signs

\begin{tabular}{|c|c|c|c|c|}
\hline \multirow{2}{*}{ Variable } & \multirow{2}{*}{ Explanation } & \multicolumn{3}{|c|}{ Expected Sign } \\
\hline & & AKP & CHP & MHP \\
\hline $\mathbf{A K P _ { i }}$ & AKP's vote share in 2011 election at province i. & & & \\
\hline $\mathbf{A K P 2 0 0 7}_{\mathrm{i}}$ & AKP's vote share in 2007 election at province i. & + & & \\
\hline $\mathbf{C H P}_{\mathbf{i}}$ & CHP's vote share in 2011 election at province i. & & & \\
\hline $\mathrm{CHP2007}_{\mathrm{i}}$ & CHP's vote share in 2007 election at province i. & & + & \\
\hline $\mathbf{M H P}_{\mathbf{i}}$ & MHP's vote share in 2011 election at province i. & & & \\
\hline MHP2007 $_{i}$ & MHP's vote share in 2007 election at province i. & & & + \\
\hline Inflation $_{\mathrm{i}}$ & The inflation level in the last year in province i. & - & + & + \\
\hline Unemployment $_{\mathbf{i}}$ & The unemployment rate in the last year in province $i$. & - & + & + \\
\hline Growth $_{\mathrm{i}}$ & $\begin{array}{l}\text { The annual growth rate of tax collection in province i } \\
\text { since } 2007 \text { election. }\end{array}$ & + & - & - \\
\hline PubExpenditure $_{i}$ & $\begin{array}{l}\text { The annual per capita public expenditure in province } \\
\text { I since } 2007 \text { election }\end{array}$ & + & - & - \\
\hline $\begin{array}{l}\text { Region } 1 G r w t h_{i} \\
\text { Region2Grwth }_{i}\end{array}$ & Interaction dummies of growth rate with regions. & $?$ & $?$ & $?$ \\
\hline $\begin{array}{l}\text { Region1PbSpnd }_{\mathrm{i}} \\
\text { Region2PbSpnd }_{\mathrm{i}}\end{array}$ & Interaction dummies of public spending with regions. & $?$ & $?$ & $?$ \\
\hline $\begin{array}{l}\text { Region1 } \\
\text { Region2 }\end{array}$ & $\begin{array}{l}\text { Region dummies determined by Akarca and } \\
\text { Baslevent (2009) }\end{array}$ & $?$ & $?$ & $?$ \\
\hline
\end{tabular}

Table 3

Descriptive Statistics

\begin{tabular}{l|c|c|c|c|c}
\hline Variable & Obs & Mean & Std. Dev. & Min & Max \\
\hline AKP 2011 & 81 & .509 & .132 & .162 & .696 \\
\hline CHP 2011 & 81 & .210 & .134 & .009 & .562 \\
\hline MHP 2011 & 81 & .137 & .075 & .005 & .412 \\
\hline AKP 2007 & 81 & .479 & .126 & .124 & .716 \\
\hline CHP 2007 & 81 & .165 & .0932 & .019 & .401 \\
\hline MHP 2007 & 81 & .141 & .0746 & .009 & .450 \\
\hline Inflation & 81 & 7.376 & .481 & 5.83 & 8.23 \\
\hline Unemployment & 81 & 10.658 & 2.997 & 6.1 & 17 \\
\hline Tax Growth & 81 & 14.177 & 7.011 & -.76 & 45.57 \\
\hline Public Expenditure & 81 & 1878.487 & 850.620 & 976.47 & 7069.01 \\
\hline
\end{tabular}


Table 4

Coefficient Estimates and Standard Errors

\begin{tabular}{|c|c|c|c|}
\hline & AKP 2011 & CHP 2011 & MHP 2011 \\
\hline \multirow[t]{2}{*}{ AKP 2007} & 0.919 & & \\
\hline & $(0.046)^{* * * *}$ & & \\
\hline \multirow[t]{2}{*}{ Inflation } & 0.000 & 0.015 & -0.013 \\
\hline & $(0.009)$ & $(0.014)$ & $(0.009)$ \\
\hline \multirow[t]{2}{*}{ Unemployment 2010} & -0.002 & -0.001 & -0.000 \\
\hline & $(0.001)^{*}$ & $(0.002)$ & $(0.002)$ \\
\hline \multirow[t]{2}{*}{ Tax Growth } & 0.003 & 0.004 & -0.002 \\
\hline & $(0.001)^{* *}$ & $(0.003)$ & $(0.001)^{*}$ \\
\hline \multirow[t]{2}{*}{ Public Expenditure } & 0.000 & 0.000 & -0.000 \\
\hline & $(0.000)$ & $(0.000)^{* * *}$ & $(0.000)^{* * *}$ \\
\hline \multirow[t]{2}{*}{ Region 1 Growth } & -0.003 & -0.004 & 0.003 \\
\hline & $(0.001)^{*}$ & $(0.002)$ & $(0.001)^{*}$ \\
\hline \multirow[t]{2}{*}{ Region 2 Growth } & -0.003 & -0.003 & 0.002 \\
\hline & $(0.002)$ & $(0.003)$ & $(0.002)$ \\
\hline \multirow[t]{2}{*}{ Public Expenditure x Region 1} & -0.000 & -0.000 & 0.000 \\
\hline & $(0.000)$ & $(0.000)^{* * * *}$ & $(0.000)^{* *}$ \\
\hline \multirow[t]{2}{*}{ Public Expenditure x Region 2} & -0.000 & -0.000 & 0.000 \\
\hline & $(0.000)$ & $(0.000)^{* * *}$ & $(0.000)$ \\
\hline \multirow[t]{2}{*}{ Region 1} & 0.164 & 0.336 & -0.089 \\
\hline & $(0.045)^{* * *}$ & $(0.077)^{* * *}$ & $(0.045)^{* * *}$ \\
\hline \multirow[t]{2}{*}{ Region 2} & 0.178 & 0.428 & -0.083 \\
\hline & $(0.045)^{* * *}$ & $(0.074)^{* * *}$ & $(0.042)^{* * *}$ \\
\hline \multirow[t]{2}{*}{ CHP 2007} & & 0.580 & \\
\hline & & $(0.0106)^{* * *}$ & \\
\hline \multirow[t]{2}{*}{ MHP 2007} & & & 0.833 \\
\hline & & & $(0.063)^{* * * *}$ \\
\hline \multirow[t]{2}{*}{ Constant } & -0.061 & -0.308 & 0.180 \\
\hline & $(0.094)$ & $(0.127)^{* * *}$ & $(0.079)^{* *}$ \\
\hline $\mathbf{R}^{2}$ & $92.49 \%$ & $82.40 \%$ & $78.81 \%$ \\
\hline
\end{tabular}

Note: Values in parenthesis are $t$-statistics. $* * *, * *$ and $*$ denote significance levels at the $1 \%$, $5 \%$ and 10\% levels, respectively. As the dependent variable, AKP 2011, CHP 2011 and MHP 2011 indicate the vote shares of the parties in the 2011 general elections. 
Moreover, regional interaction dummies suggested that economic growth was less influential in Region 1. To repeat, Akarca (2009b) describes Region 2 as that where voters have above average income and education levels, whereas Region 3 consists of provinces that are less-developed and are populated mostly by ethnic Kurds. In fact, the MHP benefited from the economic growth in Region 1 provinces. $(-0.0026+0.0029>0)$ We can speculate that Region 1 voters are more sensitive to the political policies of the AKP than voters in other regions. Media reports indicate that specific AKP policies related to the "Kurdish Issue" are considerably criticized by the voters in Region 1 provinces which can loosely describe as more conservative.

Another economic indicator which might influence the voting behaviors of citizens is unemployment. In fact, it may be claimed that the unemployment rate is of more importance for the society than income growth since its economic and psychological effects are much more significant for the unemployed, their relatives and their friends. Our data indicated that the incumbent party AKP won fewer votes in the provinces where the unemployment rate was high in $2010 .^{[12]}$ The opposition parties were not affected by unemployment rates.

The last economic indicator which we employed was the inflation rate. In the 1980's and 1990's, inflation was one of the biggest economic and social problems in Turkey. Governments have implemented decisive disinflation policies since 1998 and have managed to decrease the inflation rate from the high double digits (85\% in 1998) to single digits (approximately 5\% in 2010). Both the AKP government and the Central Bank emphasize that keeping the inflation rate at a low level is one of the main policy concerns. So, inflation is one of the closely followed macroeconomic indicators in Turkey. However, our estimations suggest that inflation does not affect the voting behavior. Coefficients of the incumbent party and the opposition party vote share estimations that are statistically insignificant. Some arguments can be presented here to explain this insignificance. First, there is not enough variation among inflation rates across regions; the minimum rate is $5.83 \%$ while the maximum rate is $8.23 \%$. Voters might not notice and/or care about minor differences in inflation. Remember that inflation data are not available on the provincial level but on the administrative regional level created by the Turkish Statistical Institute. There are 81 provinces but only 26 administrative regions. Moreover, what we measure by our estimations is what portion of the variation the AKP vote shares across provinces can be attributed to variation in the provincial inflation rates. That is, if the inflation rate is lower in province $\mathrm{A}$ than in province $\mathrm{B}$, did this situation cause the AKP votes to increase relatively more in province $\mathrm{A}$ than in province $\mathrm{B}$ ? If the AKP managed to reduce inflation rates of all provinces by similar rates, then the coefficient of the inflation would be close to zero despite the major impact. Therefore,

\footnotetext{
${ }^{[12]}$ We used the unemployment rate 2010 rather than the difference in unemployment rate between 2007 and 2011 as we did for the economic growth rate because unemployment is generally temporary while the effects of economic growth is not. Moreover we also believe that creating jobs is generally considered to be a duty of the governments. So if in province A the unemployment rate is $20 \%$ in 2011 , it is still going to be failure of the government even if the unemployment rate was $20 \%$ in 2006. Due to similar reasons we used the inflation rate in the one year prior to the 2011 election.
} 
we could detect a cross-sectional but not a time series impact of the inflation on vote shares of the parties. ${ }^{[13]}$

Social transfer programs and other government expenditures can also affect the satisfaction of the voters with the incumbent party policies. Prior to the elections, it was argued that public transfer payments were increased in order to sway constituents' votes. So, in order to test the effect of public expenditure on the voting behavior, we included the provincial per capita public expenditure of the year prior to the 2011 election in the estimations. However, data revealed that high public expenditures did not increase the AKP's vote share at all. In fact, results indicated that public expenditures increased the votes of the CHP in Region 3 and likewise the votes of the MHP in Region 1.

Finally, we investigated whether there were any regional effects on the results of the election. The null hypotheses were rejected for all parties, which implied that regional and/ or ethnic factors played significant roles in determining the votes cast for the AKP, CHP and MHP. The coefficient estimates were interpreted in relation to the omitted region, i.e., Region 3. The coefficients of both Region 1 and Region 2 were significantly positive in the equation of the AKP suggesting that the AKP received more votes in these regions. Region 3 is the region of mostly Kurdish citizens and the BDP has the strongest base. The AKP had a relative success in that region in the 2007 election. However, according to many people, Prime Minister Tayyip Erdoğan distanced himself from parliament members of the DTP (Democratic Society Party, the predecessor of the BDP) after the election. In addition, it was argued that Erdoğan adopted a relatively nationalistic rhetoric prior to the election in order to attract core voters from the MHP which was believed to have trouble with the election threshold of $10 \%$. This nationalistic approach might have caused many Kurdish voters to shift from the AKP to the BDP in the election. Results related to the CHP and the MHP also showed that both the CHP and the MHP received fewer votes in Region 3 when compared to Region 1. Likewise, the CHP had more votes in Region 1 and 2 than in Region 3. According to political analysts, independent candidates who were traditionally making politics within the "Ethnic Kurdish" party the BDP became very successful in organizing and moving their constituents in Region 3. This might also explain the relative "failure" of the two main parties in the region.

\section{Conclusion}

The 2011 general election resulted in an impressive victory for the ruling party the AKP. It won its third term in parliamentary elections by receiving about half of the votes and became the first political party to win three consecutive elections with an increase in its vote share in each general election. Despite the increase in its vote share, the number of the AKP representatives in the parliament decreased. Thus, the AKP could not reach the two-thirds majority needed to amend the constitution unilaterally or to bring a new constitution to a referendum.

\footnotetext{
${ }^{[13]}$ By using time series data, Akarca (2011) estimated that each percentage point in inflation rate lowers the incumbent party vote by 0.12 percentage points.
} 
According to our results, the vote shares obtained in the previous election by three parties in the respective province had significant and positive effects on the vote share gained in the 2011 general election. Results show that the political parties preserved their party loyalists or sympathizers between the two general elections.

We also examined the effects of economic conditions on the incumbent and opposition party votes. We found that the incumbent party received more votes in the provinces where economic growth was high, as expected. The MHP votes decreased in the provinces where economic growth was high while the CHP was not negatively affected by it. This can be due to the fact that the AKP and MHP party bases are socially and ideologically closer to each other than the AKP and CHP party bases. Therefore, economic factors might influence voters to choose between the AKP and MHP but not between the AKP and CHP. Another variable used to examine the effect of the economic situation on party preferences was unemployment. Our data indicated that the incumbent party AKP received fewer votes in the provinces where the unemployment rate was high in 2010. Opposition parties did not lose votes due to unemployment rates. We also found that higher public expenditure did not improve the vote share of the ruling party. In fact, our results indicated that higher public expenditures increased the votes of the CHP in Region 3 and those of the MHP in Region 1. This result implies that incumbent party policies such as social transfer programs and other government expenditures do not affect the satisfaction of the voters. Another explanation which can be made according to this result is that the incumbent party's social transfer programs and other government expenditures were implemented in the provinces where the ruling party's vote share was on the margin. The government did not use too much public money in the provinces where the AKP and the opposition parties have a strong voting base.

Finally, regional and/or ethnic factors were of paramount importance in determining the votes cast for the AKP, CHP and MHP. Our results revealed that the AKP increased its votes more in the provinces where the voters have average or high income and education levels.

\section{References}

Akarca, A.T. (2011). "A Prediction for AKP's Nationwide Vote Share in the 12 June 2011 Turkish Parliamentary Election." Iktisat Işletme ve Finans, 26(302): 53-74.

-----, (2009a). “A Prediction for AKP's Nationwide Vote Share in the 29 March 2009 Turkish Local Elections.” Iktisat Issletme ve Finans, 24(276): 7-22.

------, (2009b) "Putting the Outcome of the 29 March 2009 Turkish Local Administrations Election in Perspective." Paper presented at EconAnadolu 2009: Anadolu International Conference in Economics. June 17-19, 2009, Eskişehir, Turkey.

Akarca, A.T. and Baslevent, C. (2009) "A Cluster Analysis of Regional Voting Patterns in Turkey from 1999 to 2009." Unpublished manuscript.

Akarca, A.T. and Tansel, A. (2007). "Social and Economic Determinants of Turkish Voter Choice in the 1995 Parliamentary Election.” Electoral Studies, 26: 633-647. 
-----, (2006). "Economic Performance and Political Outcomes: An Analysis of the Turkish Parliamentary and Local Election Results between 1950 and 2004." Public Choice, 129(1-2): 77-105.

------, (2002). "Economic Performance and Political Outcomes: An Analysis of the 1995 Turkish Parliamentary Election Results." Paper presented at the Ninth Annual Conference of the Economic Research Forum held in Sharjah, UAE, October.

Başlevent, C., Kirmanoğlu, H., and Şenatalar, B. (2005). "Empirical Investigation of Party Preferences and Economic Voting in Turkey." European Journal of Political Research, 44: 547-562.

Çarkoğlu, A. (1997). "Macro-economic Determinants of Electoral Support for Incumbents in Turkey, 1950-1995." New Perspectives on Turkey, 17: 75-96.

Ercins, G. (2007). “Türkiye'de Sosyo-Ekonomik Faktörlere Bağlı Olarak Değişen Seçmen Davranış1 (The Voter Behevior in Turkey Changing According to the Socio-Economic Variables)" C.Ü. Iktisadi ve İdari Bilimler Dergisi, 8(2): 25-40.

Evans, T.A. (2006). "The Different Effects of Discretionary Federal Spending on Parliamentary Elections." Economic Inquiry, 42: 234-48.

Evans, G., Robert A. (2006). "The Political Conditioning of Economic Perceptions". Journal of Politics, 68:194-207.

Fraile, M. and. Lewis-Beck, M.S. (2010). "Economic Voting in Spain: A 2000 Panel Test.” Electoral Studies 29 (2): 210-220.

Gerber, A.S. and Gregory A.H. (2009). "Partisanship and Economic Behavior: Do Partisan Differences in Economic Forecasts Predict Real Economic Behavior?” American Political Science Review, 103(3): 407-426.

Göksel, T. and Çınar, Y. (2011). Mevcut Seçim Sisteminin İyileştirilmesine Yönelik Sayısal Analizler ve Politika Önerileri (Quantitative Analysis and Policy Recommendations for the Improvement of the Existing Electoral System)", TEPAV Yayınları, No: 58.

Köksal B., Civan, A., and Genç, S. (2010) "An Analysis of the Shifts in the Voter Preferences in 2009 Turkish Local Elections." İktisat İsletme ve Finans, 25 (289): 9-28.

Lewis-Beck, M.S. and Stegmaier, M. (2000). Economic Determinants of Electoral Outcomes. Annual Review of Political Science, 3: 183-219.

Nannestad, P. and Paldam, M. (1994) "The VP Function: A Survey of the Literature on Vote and Popularity Functions after 25 Years.” Public Choice 79 (3-4): 213-245.

Paldam, M. (1991). "How Robust Is the Vote Function? A Study of Seventeen Nations over Four Decades," in H. Norpoth, S. Michael, M.S. Lewis-Beck, L.D. Lafay (eds.) Economics and Politics: The Calculus of Support: 9-33. University of Michigan Press.

West, W.J. (2005). "Regional Cleavages in Turkish Politics: An Electoral Geography of the 1999 and 2002 National Elections.” Political Geography, 24(4): 499-523.

Whitten, G. (2004). "Could There Have Possibly Been Economic Voting?” in M.S. Lewis-Beck (ed.) The French Voter Before and After the 2002 Elections: 126-135. Hampshire, UK: Palgrave Macmillan.

Yüksel, H., Civan, A., and Gündoğan, E. (2011). "The Impact of Economic and Political Factors on the 2010 Turkish Referendum.” Eurasian Journal of Business and Economics, 4 (7): 69-80. 
